Vol. VII No. 3, Desember 2014

P-ISSN: $1979-858 \mathrm{X}$

Halaman 153 - 161

\title{
EFISIENSI MODAL INTELEKTUAL DAN DAMPAKNYA TERHADAP KINERJA PERUSAHAAN
}

\author{
Istianingsih Sastrodiharjo \\ Universitas Mercu Buana
}

\begin{abstract}
This study aimed to analyze the effect of intellectual capital efficiency of the financial performance and the performance of the company's shares. Measurement of financial performance with return on equity (ROE), earnings per share (EPS), while the company's stock performance is measured by the cumulative abnormal return (CAR). The total sample in this study was 108 companies and individual company data taken 3 years from 2009 to 2011. The hypothesis testing with multiple linear regression method. Results from this study showed that the intellectual capital positive effect on ROE and EPS. However, intellectual capital is not proven effect on CAR. The main implication of this study for the management of the company for more attention to the management of intellectual capital because it is proven to improve the performance of the company.
\end{abstract}

Keywords: Intellectual Capital, Financial Performance, Stock Prices

ABSTRAK: Penelitian ini bertujuan untuk menganalisis pengaruh efisiensi modal intelektual terhadap kinerja keuangan dan kinerja saham perusahaan. Kinerja keuangan diukur dengan return on equity (ROE), earnings per share (EPS), sedangkan kinerja saham perusahaan diukur dengan cumulative abnormal return (CAR). Total sampel dalam penelitian ini adalah 108 perusahaan dan masing- masing perusahaan diambil data 3 tahun dari tahun 2009 sampai dengan 2011. Pengujian hipotesis dengan metode regresi linier berganda. Hasil dari penelitian ini menunjukan bahwa modal intelektual berpengaruh positif terhadap ROE dan EPS. Akan tetapi modal intelektual tidak terbukti berpengaruh terhadap CAR. Implikasi utama penelitian ini bagi manajemen perusahaan agar lebih memperhatikan pengelolaan modal intelektual karena terbukti dapat meningkatkan kinerja perusahaan.

Kata kunci: Modal Intelektual, Kinerja Keuangan, Harga Saham

\footnotetext{
${ }^{1}$ Draft pertama: 21 September 2014 ; Revisi: 20 Oktober 2014 ; Diterima: 15 November 2014

Penulis dapat dikontak melalui: istisastro@yahoo.com
} 


\section{PENDAHULUAN}

Modal intelektual merupakan salah satu aset tak berujud yang berkontribusi tinggi terhadap keberlangsungan usaha. Para pelaku bisnis mulai menyadari bahwa kemampuan bersaing tidak hanya terletak pada kepemilikan aktiva berwujud, tetapi lebih pada inovasi, sistem informasi, pengelolaan organisasi dan sumber daya manusia yang dimilikinya. Salah satu bentuk asset tidak berwujud adalah pengetahuan. Pengetahuan diakui sebagai komponen esensial bisnis dan sumber daya strategis yang lebih sustainable (berkelanjutan) untuk memperoleh dan mempertahankan competitive advantage (Asni, 2007). Starovic et.al.(2003) menemukan bahwa pengetahuan telah menjadi mesin baru dalam pengembangan suatu bisnis. Salah satu pendekatan yang digunakan dalam penilaian dan pengukuran knowledge asset (aset pengetahuan) tersebut adalah modal intelektual yang telah menjadi fokus perhatian dalam berbagai bidang, baik manajemen, teknologi informasi, sosiologi, maupun akuntansi (Petty dan Guthrie, 200o).

Chen et al., (2005) menyatakan bahwa modal intelektual juga dapat dijadikan sebagai sebagai indikator kinerja keuangan masa depan perusahaan. Masalah yang seringkali muncul adalah bagaimana mengukur efisiensi dari modal intelektual perusahaan. Salah satu cara untuk mengukur kinerja modal intelektual adalah dengan menggunakan data dari laporan keuangan. Pulic $(1998,1999,2000)$ mengembangkan metode untuk melihat sejauh mana modal intelektual suatu perusahaan mampu berkontribusi bagi nilai tambah perusahaan dengan suatu formula yang disebut Value Added of Intellectual Coefficient $\left(\mathrm{VAIC}^{\mathrm{TM}}\right)$.

Penelitian ini bertujuan untuk menguji pengaruh modal intelektual melalui value added intellectual capital coefficient $\left(\mathrm{VAIC}^{\mathrm{TM}}\right)$ terhadap kinerja perusahaan. Metode VAIC ${ }^{\mathrm{TM}}$ ini dikembangkan oleh Pulic (2001). Penelitian ini berbeda dengan penelitian terdahulu yang telah menunjukan hubungan antara IC yang terdiri dari human capital, structure capital, serta physical capital dengan market performance perusahaan terhadap kinerja perusahaan yang diukur berdasarkan return on equity (ROE), earnings pet share (EPS), dan annual stock return (ASR). Pada penelitian ini menggunakan variabel cumulative abnormal return (CAR) sebagai variabel dependen. Menggantikan ASR, CAR diharapkan lebih dapat merepresentasikan kinerja perusahaan dari sisi pasar (investor). Selain itu, penelitian ini menganalisis secara khusus masing-masing kategori modal intelektual (VACA, VAHU, STVA) terhadap kinerja perusahaan yang diukur dengan ROE, EPS, CAR.

Sejauh mana dampak pengelolaan modal intelektual dalam menopang kinerja perusahaan dan harga saham perusahaan merupakan topik yang menarik untuk diteliti. Penelitian ini menguji dampak efisiensi modal intelektual terhadap kinerja perusahaan. Dengan pengelolaan modal intelektual yang baik diharapkan akan meningkatkan kinerja keuangan perushaan dan pada akhirnya akan menarik minat investor untuk menanamkan modalnya pada perusahaan guna meningkatkan kualitas dan daya saing perusahaan.

\section{KERANGKA TEORI DAN PENGEMBANGAN HIPOTESIS}

Teori Resource-Based View (RBV) menyatakan bahwa sumberdaya perusahaan yang unik dan tidak mudah ditiru oleh pesaing akan membuat perusahaan lebih mampu untuk bersaing (Barney, 1991, Cornner 1991, dan Schulze, 1992) dalam (Istianingsih, 2011). Meskipun teori ini pada dasarnya berlaku untuk sumberdaya perusahaan secara keseluruhan, namun Grant (1991) dalam (Istianingsih,2011) memisahkan antara sumberdaya dan kapabilitas. Sumberdaya termasuk tangible, intangible, dan personal-based resource. Sementara kapabilitas terkait dengan kemampuan perusahaan untuk menjalankan proses bisnis (Istianingsih,2011). Dengan mengadopsi pandangan teori RBV ini, penelitian ini memasukkan intellectual capital sebagai personal-based resource yang dimiliki perusahaan yang dapat digunakan untuk meraih sustainable competitive advantage. Menurut Istianingsih (2011), intellectual capital yang merupakan sumberdaya unik perusahaan yang 
tidak mudah ditiru, akan dapat membantu perusahaan dalam meningkatkan daya saing yang berkelanjutan. Dengan demikian, modal intelektual perlu dikelola dengan baik untuk mendapatkan manfaat yang optimal (Istianingsih, 2011).

Modal intelektual dalam penelitian ini didefinisikan sebagai sumberdaya tidak berwujud berupa pengetahuan, pengalaman, kemampuan mengelola hubungan, pengorganisaian teknologi dan informasi, ketrampilan, dan profesionalitas yang dapat dikelola dan dimanfaatkan oleh manajemen untuk menciptakan nilai guna meraih keunggulan dalam bersaing yang berkelanjutan bagi perusahaan (Istianingsih, 2012). Definisi modal intelektual ini merupakan definisi yang berasal dari penelitian terbaru dan merupakan definisi yang lengkap karena lebih menggambarkan pengertian modal intelektual secara menyeluruh. Pulic $(1998,2001)$ mengembangkan "Value Added Intellectual Coefficient" $\left(\mathrm{VAIC}^{\mathrm{TM}}\right)$ untuk mengukur modal intelektual perusahaan. Pulic berfokus dengan dua aspek penting dalam penilaian dan penciptaan nilai yang belum terpecahkan yaitu bahwa 1) modal intelektual berbasis pasar tidak dapat dihitung untuk perusahaan yang tidak terdaftar di bursa saham sehingga perlu cara alternatif untuk menentukan modal intelektual berbasis pasar. 2) Tidak ada sistem yang memadai untuk pemantauan efisiensi kegiatan bisnis saat ini yang dilakukan oleh karyawan, apakah potensi mereka diarahkan menambah penciptaan nilai atau pengurangan nilai. Model ini dimulai dengan kemampuan perusahaan untuk menciptakan value added (VA). VA adalah indikator paling objektif untuk menilai keberhasilan bisnis dan menunjukkan kemampuan perusahaan dalam penciptaan nilai (value creation) (Pulic, 2001). VA dihitung sebagai selisih antara output dan input (Pulic, 2001). Tan et al. (2007) menyatakan bahwa output (OUT) merepresentasikan revenue dan mencakup seluruh produk dan jasa yang dijual di pasar, sedangkan input (IN) mencakup seluruh beban yang digunakan dalam memperoleh revenue. Menurut Tan et al. (2007), hal penting dalam model ini adalah bahwa beban karyawan (labour expenses) tidak termasuk dalam IN. Karena peran aktifnya dalam proses value creation, intellectual potential (yang direpresentasikan dengan labour expenses) tidak dihitung sebagai cost dan tidak masuk dalam komponen IN (Pulic, 2001). Karena itu, aspek kunci dalam model Pulic (2001) adalah memperlakukan tenaga kerja sebagai entitas penciptaan nilai (value creating entity) (Tan et al., 2007). VA dipengaruhi oleh efisiensi Human Capital (HC) dan Structural Capital (SC).Pulic (2001) membagi VAIC ${ }^{\mathrm{TM}}$ menjadi value added capital coefficient (VACA), value added human capital coefficient (VAHU), dan structural capital coefficient (STVA).Value Added Capital Coefficeint (VACA) merupakan indikator bahwa VA diciptakan oleh satu unit modal fisik. Pulic (2001) berasumsi bahwa jika unit CA menghasilkan keuntungan yang lebih besar dalam satu perusahaan dari yang lain, maka perusahaan pertama merupakan perusahaan memanfaatkan CA dengan lebih baik. Dengan demikian, pemanfaatan CA yang lebih baik adalah bagian dari IC perusahaan.Bila dibandingkan lebih dari sekelompok perusahaan, VACA menjadi indikator dari kemampuan intelektual perusahaan untuk lebih memanfaatkan modal fisik. VACA = VA/CA (Pulic, 2001).

Human Capital Coefficient (VAHU) menunjukkan berapa banyak VA diciptakan oleh satu rupiah yang dihabiskan untuk karyawan. Hubungan antara VA dan HC menunjukkan kemampuan untuk menciptakan nilai HC dalam sebuah perusahaan. Konsisten dengan pandangan penulis IC terkemuka lainnya (Edvinsson, 1997; Sveiby, 1998; Pulic, 1998 dalam Tan et al., 2007) berpendapat bahwa total biaya gaji dan upah merupakan indikator perusahaan HC. Pulic (2001) berpendapat bahwa sejak pasar menentukan gaji sebagai akibat dari kinerja, secara logis dapat disimpulkan bahwa keberhasilan HC harus dinyatakan dengan kriteria yang sama. Dengan demikian, hubungan antara VA dan HC menunjukkan kemampuan untuk menciptakan nilai HC dalam sebuah perusahaan. Demikian pula, jika dibandingkan dengan lebih dari satu kelompok perusahaan, VAHU menjadi indikator kualitas sumber daya manusia dari perusahaan dan kemampuan mereka 
untuk menghasilkan VA untuk setiap rupiah yang dikeluarkan untuk HC. VAHU $=$ VA/HC (Pulic, 2001).

Structural Capital Coefficient (STVA) menunjukkan kontribusi modal struktural (SC) dalam penciptaan nilai. Dalam model Pulic, SC adalah VA dikurangi HC. Apabila kontribusi dalam penciptaan nilai HC kurang, maka semakin besar kontribusi dari SC. Dalam Tan et al. (2007), Pulic (2001) berpendapat, hal ini telah diverifikasi oleh penelitian empiris yang menunjukkan sektor industri tradisional. Dalam industri berat dan pertambangan misalnya, VA hanya sedikit lebih besar dari HC, dengan komponen SC yang tidak signifikan. Di sisi lain, dalam industri farmasi dan sektor perangkat lunak, situasi yang sama sekali berbeda diamati. HC menciptakan hanya 25-40 persen dari seluruh VA dan kontribusi besar disebabkan oleh SC. Oleh karena itu, hubungan antara ketiga VA dan SC yang digunakan dihitung dengan cara yang berbeda karena HC dan SC berada dalam proporsi terbalik sejauh menyangkut penciptaan nilai. STVA mengukur jumlah SC yang diperlukan untuk menghasilkan rupiah dari VA dan merupakan indikasi bagaimana SC sukses dalam penciptaan nilai.Tidak seperti VACA dan VAHU, VA adalah pada penyebut untuk STVA. STVA = SC/VA (Pulic, 2001).

Salah satu elemen dari modal intelektual adalah relational capital (Bontis,20oo). Relational capital merupakan hubungan yang hamonis yang dimiliki oleh perusahaan dengan para mitranya, baik yang berasal dari para pemasok yang andal dan berkualitas, pelanggan yang loyal dan merasa puas, hubungan perusahaan dengan pemerintah, maupun dengan masyarakat sekitar (Bontis, 2000).Hal ini merupakan bentuk nyata hubungan antara modal intelektual dengan kinerja perusahaan. Dengan adanya relational capital yang baik dalam perusahaan maka seluruh mitra perusahaan dalam hal ini pemasok, pelanggan, pemerintah, dan masyarakat akan percaya kepada perusahaan. Hal ini dapat menarik para investor untuk menginvestasikan dananya kepada perusahaan sehingga nilai perusahaan di pasar akan meningkat. Karena kepercayaan para investor kepada perusahaan, maka imbal balik saham juga akan meningkat. Hal ini menunjukan adanya hubungan positif antara modal intelektual dengan kinerja perusahaan. Berdasarkan teori tersebut diajukan hipotesis sebagai berikut:

Hı: Kinerja Modal Intelektual (VAIC) berpengaruh positif terhadap kinerja keuangan (ROE)

H1.a: Kinerja physical capital (VACA) berpengaruh positif terhadap kinerja keuangan (ROE)

H1.b: Kinerja human capital (VAHU) berpengaruh positif terhadap kinerja keuangan (ROE)

H1.c: Kinerja structural capital (STVA) berpengaruh positif terhadap kinerja keuangan (ROE)

H2: Kinerja Modal Intelektual (VAIC) berpengaruh positif terhadap kinerja keuangan (EPS)

H2.a: Kinerja physical capital (VACA) berpengaruh positif terhadap kinerja keuangan (EPS)

H2.b:Kinerja human capital (VAHU) berpengaruh positif terhadap kinerja keuangan (EPS)

H2.c: Kinerja structural capital (STVA) berpengaruh positif terhadap kinerja keuangan (EPS)

H3: Kinerja Modal Intelektual (VAIC) berpengaruh positif terhadap return saham perusahaan (CAR)

H3.a: Kinerja physical capital (VACA) berpengaruh positif terhadap return saham perusahaan (CAR)

H3.b: Kinerja human capital (VAHU) berpengaruh positif terhadap return saham perusahaan (CAR).

H3.c: Kinerja structural capital (STVA) berpengaruh positif terhadap return saham perusahaan (CAR). 


\section{METODE PENELITIAN}

Obyek penelitian ini adalah modal intelektual yang diukur berdasarkan VAIC $^{\mathrm{TM}}$ dalam Pulic (2000). VAIC ${ }^{\mathrm{TM}}$ terdiri atas physical capital (VACA), human capital (VAHU), dan structural capital (STVA) sebagai variabel bebas dan return on equity (ROE), earnings per share (EPS), dan cumulative abnormal return (CAR) sebagai variabel terikat. Unit observasi pada penelitian ini adalah perusahaan - perusahaan manufaktur yang terdaftar di Bursa Efek Indonesia pada periode 2009-2011. Alasan pemilihan obyek penelitian ini adalah untuk mengetahui apakah imbal hasil saham perusahaan yang dilihat berdasarkan ROE, EPS, dan CAR dipengaruhi oleh faktor seperti VACA, VAHU, dan STVA. Perusahaan manufaktur dipilih sebagai subjek penelitian karena pengukuran IC akan lebih akurat dalam industri sejenis. Periode 2009-2011 dipilih sebagai tahun penelitian karena data-data pada tahun tersebut sudah lengkap dan paling up-to-date.

Populasi dalam penelitian ini adalah seluruh perusahaan manufaktur yang terdaftar di Bursa Efek Indonesia periode 2009-2011.Metode yang digunakan untuk pemilihan sampel dalam penelitian ini adalah metode purposive sampling, dengan kriteria sampel merupakan (1) perusahaan yang terdaftar di Bursa Efek Indonesia selama periode penelitian, (2) laporan keuangan disajikan dalam mata uang rupiah, (3) menerbitkan laporan keuangan tahunan yang telah diaudit oleh akuntan publik untuk tahun 2009-2011, dan (4) mempunyai laporan keuangan yang lengkap dari tahun 2009-2011 (5) tanggal cut-off laporan keuangan 31 Desember.

\section{Definisi Operasional Variabel}

Efisiensi atau kinerja modal intelektual dalam penelitian ini adalah besaran Value Added Intellectual Coefficient $\left(\mathrm{VAIC}^{\mathrm{TM}}\right)$ yang mengindikasikan kemampuan intelektual organisasi. VAIC ${ }^{\mathrm{TM}}$ dapat juga dianggap sebagai BPI (Business Performance Indicator). Variabel ini terdiri dihitung dengan rumus Pulic (2001) seperti dijelaskan pada bagian 2.

$$
\mathrm{VAIC}^{\mathrm{TM}}=\mathrm{VACA}+\mathrm{VAHU}+\text { STVA }
$$

Formulasi perhitungan value added adalah sebagai berikut (Ghozali, 2008):

Output $(\mathrm{OUT})=$ Total penjualan dan pendapatan lain.

Input (IN) = Beban dan biaya-biaya (selain beban karyawan).

Value Added (VA): Selisih antara Output dan Input.

$$
\text { VA }=\text { OUT - IN }
$$

Human Capital $(H C)=$ Beban karyawan.

Capital Employed/Capital Coifficient (CA) = Dana yang tersedia (ekuitas, laba bersih).

Structural Capital $(S C)=$ VA $-\mathrm{HC}$

Value Added Capital Coifficient (VACA)

VACA adalah rasio dari VA terhadap CA. Rasio ini menunjukkan kontribusi yang dibuat oleh setiap unit dari CA terhadap value added organisasi:

$$
\mathrm{VACA}=\mathrm{VA} / \mathrm{CA}
$$

Value Added Human Capital (VAHU)

VAHU adalah rasio dari VA terhadap HC. Rasio ini menunjukkan kontribusi yang dibuat oleh setiap rupiah yang diinvestasikan dalam HC terhadap value added organisasi:

$$
\mathrm{VAHU}=\mathrm{VA} / \mathrm{HC}
$$


STVA adalah rasio dari SC terhadap VA. Rasio ini mengukur jumlah SC yang dibutuhkan untuk menghasilkan 1 rupiah dari VA dan merupakan indikasi bagaimana keberhasilan SC dalam penciptaan nilai:

$$
\text { STVA }=\text { SC/VA }
$$

Variabel dependen dalam penelitian ini adalah kinerja perusahaan yang diukur dengan kinerja keuangan dan kinerja pasar (saham) yaitu 1) Return on Equity (ROE) yang mengukur seberapa banyak keuntungan sebuah perusahaan dapat menghasilkan setiap rupiah dari modal pemegang saham. Rumus untuk memperoleh ROE adalah Laba Pemegang saham dibagi dengan Jumlah dana pemegang saham. 2) Earnings per share (EPS) yang merupakan ukuran profitabilitas yang menggabungkan keputusan operasi, investasi dan pembiayaan (Tan et al., 2007). Formula untuk memperoleh EPS adalah (Ghozali, 2008) yaitu Laba pemegang saham dibagi dengan Rata-rata tertimbang jumlah saham. 3). Cumulative abnormal return (CAR) yang merupakan penjumlahan abnormal return saham selama periode pengamatan yaitu abnormal return selama tahun 2009 - 2011 pada hari laporan keuangan diterbitkan.

$$
\begin{aligned}
& \mathrm{CAR}=\sum A R_{i t}(\text { Suwardjono, 1997) } \\
& \mathrm{AR}_{\mathrm{it}} \quad=\mathrm{R}_{\mathrm{it}}-\mathrm{RM}_{\mathrm{t}} \\
& \mathrm{R}_{\mathrm{it}} \quad=\left(P_{i t}-P_{i t-1}\right) /\left(P_{i t-1}\right) \\
& \mathrm{RM}_{\mathrm{t}} \quad=\left(I H S G_{t}-I H S G_{t-1}\right) / I H S G_{t-1}
\end{aligned}
$$

Di mana: $\mathrm{AR}_{\mathrm{it}}$; return abnormal individu perusahaan $\mathrm{i}$ periode $\mathrm{t}$ (hari); $\mathrm{R}_{\mathrm{it}}$ adalah return individu sesungguhnya (actual return) perusahaan i pada periode $t$ (hari). $\mathrm{RM}_{\mathrm{t}}$ merupakan return pasar periode $\mathrm{t}$ (hari). $\mathrm{CAR}_{\mathrm{it}}$ adalah return abnormal kumulatif perusahaan i selama 1 tahun dari 1 April sampai dengan 31 Maret. $\mathrm{P}_{\text {it }}$ adalah harga saham penutupan (closing price) perusahaan $\mathrm{i}$ pada periode $\mathrm{t}$ (hari). $\mathrm{P}_{\mathrm{it}-\mathrm{a}}$ adalah harga saham penutupan perusahaan i pada periode sebelum $t$ (hari). IHSG $_{t}$ adalah indeks harga saham gabungan pada periode $\mathrm{t}$ (hari). $\mathrm{IHSG}_{\mathrm{t}-1}$ adalah indeks harga saham gabungan pada periode sebelum $\mathrm{t}$ (hari). Penelitian ini memasukkan juga 2 variabel kontrol sebagai faktor yang mempengaruhi kinerja perusahaan yaitu ukuran perusahaan dan struktur modal atau tingkat hutang. Ukuran perusahaan dihitung dari Logaritma total aset. Sedangkan Leverage dihitung berdasarkan proporsi hutang dibandingkan dengan ekuitas perusahaan. Penelitian ini menggunakan data sekunder berupa data kuantitatif mengenai data return on equity, earnings per share, dan cumulative abnormal return yang diperoleh akan diolah dengan menggunakan metode analisis regresi berganda dengan model regresi sebagai berikut:

\section{Model 1.}

$\mathrm{ROE}=\alpha_{0}+\alpha_{1}$ VAIC $+\alpha_{2}$ Size $+\alpha_{3}$ Leverage $+\mathrm{e}$

1a., ROE $=\alpha_{0}+\alpha_{1}$ VACA $+\alpha_{2}$ VAHU $+\alpha_{3}$ STVA $+\alpha_{4}$ Size $+\alpha_{5} \quad$ Leverage $+\mathrm{e}$

Model 2.

EPS $\quad=\alpha_{0}+\alpha_{1}$ VAIC $+\alpha_{2}$ Size $+\alpha_{3}$ Leverage $+\mathrm{e}$

$2 \mathrm{a} . \mathrm{EPS}=\alpha_{0}+\alpha_{1}$ VACA $+\alpha_{2}$ VAHU $+\alpha_{3}$ STVA $+\alpha_{4}$ Size $+\alpha_{5}$ Leverage $+\mathrm{e}$

Model 3.

$\mathrm{CAR}=\alpha_{0}+\alpha_{1} \mathrm{VAIC}+\alpha_{2}$ Size $+\alpha_{3}$ Leverage $+\mathrm{e}$

3a.CAR $=\alpha_{0}+\alpha_{1}$ VACA $+\alpha_{2}$ VAHU $+\alpha_{3}$ STVA $+\alpha_{4}$ Size $+\alpha_{5}$ Leverage $+\mathrm{e}$

Keterangan notasi sama dengan penjelasan sebelumnya.

\section{HASIL DAN PEMBAHASAN}

Berdasarkan hasil pengujian diketahui bahwa secara statistik terbukti terdapat pengaruh positif IC $\left(\right.$ VAIC $\left.^{\mathrm{TM}}\right)$ terhadap kinerja keuangan perusahaan yang diukur dengan ROE. Dengan demikian, untuk meningkatkan ROE perusahaan harus memperhatikan 
modal intelektual yang terdapat dalam perusahaan. Hal ini sesuai dengan penelitian terdahulu oleh Ghozali (2007) yang mengatakan bahwa terdapat pengaruh signifikan antara IC terhadap ROE. Elemen modal intelektual yang berpengaruh secara positif dan signifikan terhadap ROE adalah VAHU dan STVA. Hal ini menunjukan bahwa tingkat pengembalian modal akan meningkat jika perusahaan memperhatikan human capital dan modal struktural.

Tabel 1. Ringkasan Hasil Pengujian Hipotesis

\begin{tabular}{|c|c|c|c|c|c|c|}
\hline & Hipotesis & $\begin{array}{c}\text { Indep. } \\
\text { Var }\end{array}$ & $\begin{array}{c}\text { Dep. } \\
\text { Var }\end{array}$ & $\begin{array}{c}\mathrm{T} \\
\text { value }\end{array}$ & Sig. & Kesimpulan \\
\hline $\mathrm{H}_{1}$ & $\begin{array}{l}\text { Kinerja modal intelektual } \\
\left(\text { VAIC }^{\mathrm{TM}}\right) \text { berpengaruh positif } \\
\text { terhadap ROE perusahaan. }\end{array}$ & VAIC & ROE & 4,679 & 0,000 & DITERIMA \\
\hline Hia & $\begin{array}{l}\text { Kinerja physical capital } \\
\text { (VACA) berpengaruh positif } \\
\text { terhadap ROE perusahaan. }\end{array}$ & VACA & ROE & 2,916 & 0,040 & DITERIMA \\
\hline Hib & $\begin{array}{l}\text { Kinerja human capital } \\
\text { (VAHU) berpengaruh positif } \\
\text { terhadap ROE perusahaan. }\end{array}$ & VAHU & ROE & 2,728 & 0,007 & DITERIMA \\
\hline Hic & $\begin{array}{l}\text { Kinerja structural capital } \\
\text { (STVA) berpengaruh positif } \\
\text { terhadap ROE perusahaan. }\end{array}$ & STVA & ROE & 6,846 & 0,000 & DITERIMA \\
\hline $\mathrm{H}_{2}$ & $\begin{array}{l}\text { Kinerja modal intelektual } \\
\text { (VAIC) berpengaruh positif } \\
\text { terhadap EPS perusahaan. }\end{array}$ & VAIC & EPS & 2,246 & 0,025 & DITERIMA \\
\hline $\mathrm{H} 2 \mathrm{a}$ & $\begin{array}{l}\text { Kinerja physical capital } \\
\text { (VACA) berpengaruh positif } \\
\text { terhadap EPS perusahaan. }\end{array}$ & VACA & EPS & 2,828 & 0,005 & DITERIMA \\
\hline $\mathrm{H}_{2} \mathrm{~b}$ & $\begin{array}{l}\text { Kinerja human capital } \\
\text { (VAHU) berpengaruh positif } \\
\text { terhadap EPS perusahaan. }\end{array}$ & VAHU & EPS & 1,659 & 0,098 & DITOLAK \\
\hline $\mathrm{H} 2 \mathrm{C}$ & $\begin{array}{l}\text { Kinerja structural capital } \\
\text { (STVA) berpengaruh positif } \\
\text { terhadap EPS perusahaan. }\end{array}$ & STVA & EPS & 1,325 & 0,186 & DITOLAK \\
\hline $\mathrm{H}_{3}$ & $\begin{array}{l}\text { Kinerja modal intelektual } \\
\text { (VAIC) berpengaruh positif } \\
\text { terhadap imbal hasil saham } \\
\text { perusahaan. }\end{array}$ & VAIC & CAR & 0,540 & 0,590 & DITOLAK \\
\hline $\mathrm{H}_{3} \mathrm{a}$ & $\begin{array}{l}\text { Kinerja physical capital } \\
\text { (VACA) berpengaruh positif } \\
\text { terhadap imbal hasil saham } \\
\text { perusahaan. }\end{array}$ & VACA & CAR & 0,285 & 0,776 & DITOLAK \\
\hline $\mathrm{H}_{3} \mathrm{~b}$ & $\begin{array}{l}\text { Kinerja human capital } \\
\text { (VAHU) berpengaruh positif } \\
\text { terhadap imbal hasil saham } \\
\text { perusahaan. }\end{array}$ & VAHU & CAR & 0,243 & 0,086 & DITOLAK \\
\hline $\mathrm{H}_{3} \mathrm{C}$ & $\begin{array}{l}\text { Kinerja structural capital } \\
\text { (STVA) berpengaruh positif } \\
\text { terhadap imbal hasil saham } \\
\text { perusahaan. }\end{array}$ & STVA & CAR & 1,749 & 0,042 & DITERIMA \\
\hline
\end{tabular}


Pengetahuan, keterampilan, dan kompetensi sumber daya manusia di dalam perusahaan harus ditingkatkan guna meningkatkan kinerja keuangan perusahaan. Selain itu proses rutinitas perusahaan dan strukturnya yang mendukung karyawan untuk menghasilkan kinerja intelektual yang optimal juga perlu diperhatikan.

Berdasarkan penelitian terbukti bahwa terdapat pengaruh yang positif antara VAIC terhadap kinerja keuangan perusahaan yang diukur dengan EPS. Dengan demikian demi meningkatkan pendapatan yang didapat dari setiap lembar saham perusahaan, modal intelektual perlu diperhatikan oleh perusahaan. Hal ini sesuai dengan penelitian terdahulu oleh Ghozali (2007) yang mengatakan bahwa terdapat pengaruh positif antara IC terhadap EPS. Elemen modal intelektual yang berpengaruh positif terhadap EPS adalah STVA. Oleh karena itu dapat disimpulkan bahwa tingkat pendapatan per lembar saham dapat meningkat karena pengaruh yang signifikan dari variabel modal struktural. Sehingga perusahaan harus meningkatkan struktur usaha perusahaan seperti modal kepandaian yang kompetitif, formula, sistem informasi, dan proses rutinitas perusahaan yang mendukung karyawan untuk menghasilkan kinerja intelektual yang optimal.

Hasil penelitian menunjukkan tidak terdapat pengaruh yang signifikan antara VAIC dengan imbal hasil saham perusahaan yang diukur dengan CAR. Hal ini membuktikan bahwa investor belum melihat modal intelektual secara keseluruhan yang diukur dengan VAIC. Yang dilihat oleh investor hanya variabel STVA (modal struktural). Modal struktural mengacu pada cara perusahaan mengelola asetnya melalui kepandaian kompetitif, paten, sistem informasi, peraturan, dan rutinitas dalam perusahaan yang menunjukan bahwa perusahaan terus bertumbuh sepanjang waktu. Dengan demikian dapat disimpulkan bahwa investor lebih tertarik kepada perusahaan yang memiliki going concern.

\section{SIMPULAN}

Secara keseluruhan hasil penelitian ini dapat membuktikan bahwa kinerja atau efisiensi modal intelektual berpegaruh positif terhadap kinerja perusahaan baik kinerja keuangan maupun kinerja pasar. Dengan demikian sangatlah penting bagi perusahaan unutk mengelola dengan baik kepemilikan modal intelektualnya sehingga dapat mendukung perusahaan memenangkan persaingan melalui peningkatan kinerja.

\section{PUSTAKA ACUAN}

Agnes. 2008. Intellectual Capital Management. Jakarta: YAPENSI.

Astuti, Partiwi D. 2005. "Hubungan Intellectual Capital dan Business Performance." Jurnal MAKSI. Vol 5, h.34-58.

Belkaoui, Ahmed Riahi. 2003. "Intellectual Capital and Firm Performance of US Multinational Firms: A Study of The Resource-based and Stakeholder Views". Journal of Intellectual Capital.Vol. 4, No. 2, pp.215-226.

Bontis, Nick. 1998. "Intellectual Capital: an Exploratory Study that Develops Measures and Models."Management Decision.Vol. 36, No. 2, pp.63-76.

Bontis, Nick, Wiliam Chua Chong Keow dan Stanley Richardson. 20oo. "Intellectual Capital and Business Performance in Malaysian Industries." Journal of Intellectual Capital. Vol 1, No. 1, pp.85-100.

Brennan, Niamh dan Brenda Connell. 20oo. "Intellectual Capital: Current Issues and Policy Implications.” Journal of Intellectual Capital. Vol 1, No. 3, pp.206-240.

Duwi, Priyatno (2010). "Teknik Mudah dan Cepat Melakukan Analisis Data Penelitian dengan SPSS".Yogyakarta : Gava Media.

Ghozali, Imam. 2006. Structural Equation Modelling Metode Alternatif dengan Partial Least Square (PLS). Semarang: Badan Penerbit Universitas Diponegoro. 
Guthrie, James. 2001. "The Management, Measurement and The Reporting Intellectual Capital." Journal of Intellectual Capital. Vol 2, No. 1, pp.27-41.

Hidayat. 200o. "Peranan Strategis Modal Intelektual dalam Persaingan Bisnis di Era Jasa." EKUITAS. Vol 5, No. 3, 293-312.

Istianingsih, 2011."Faktor-faktor Penentu Informasi dan Kinerja Modal Intelektual dan Dampaknya Terhadap Kemampuan Imbal Hasil Saham dalam Memprediksi Laba Masa Depan Perusahaan".(Studi empiris pada perusahaan yang terdaftar di bursa efek Indonesia).Disertasi. Pascasarjana Ilmu Akuntansi Fakultas Ekonomi, Universitas Indonesia.

Jensen, C Michael dan Meckling, William H. 1976. "Theory of the firm : Managerial Behaviour, Agency Cost and Ownership Structure." Journal of Financial Economics, Oktober 1976,V.3, No. 4,pp.305-36o.

Madhani, Pankaj M. "Resource Based View (RBV) of Competitive Advantage: An Overview." http://ssrn.com/abstract=1578704. Diakses Mei 2010.

Petty, Richard dan James Guthrie. 200o. "Intellectual Capital Literature Review: Measurement, Reporting and Management." Journal of Intellectual Capital. Vol 1, No. 2, pp.155-175.

Pulic, Ante. 2001. "Measuring The Performance of Intellectual Potential in Knowledge Economy".

Purnomosidhi, Bambang. 2006. "Praktik Pengungkapan Modal Intelektual pada Perusahaan Publik di BEJ.” Jurnal Riset Akuntansi Indonesia. Vol 9, No. 1, 1-20.

Sawarjuwono, Tjiptohadi dan Agustine Prihatin Kadir. 2003. "Intellectual Capital: Perlakuan, Pengukuran dan Pelaporan (Sebuah Library Research).” Jurnal Akuntansi dan Keuangan. Vol 5, No. 1, h.31-51.

Solikhah. 2010. "Mengukur dan Mengelola Intellectual Capital." Jurnal Ekonomi dan Bisnis Indonesia. Vol 15, No.2, 247-256.

Stewart, T A. 1997. “Intellectual Capital: The New Wealth of Organizations." New York: Doubleday

Tan, Hong Pew, David Plowman dan Phil Hancock. 2007. "Intellectual Capital and Financial Returns of Companies." Journal of Intellectual Capital. Vol 8, No. 1, pp.76-95.

Ulum, Ihyaul. 2008. "Intellectual Capital Performance Sektor Perbankan di Indonesia." Paper disajikan pada SNA 11, Pontianak. 